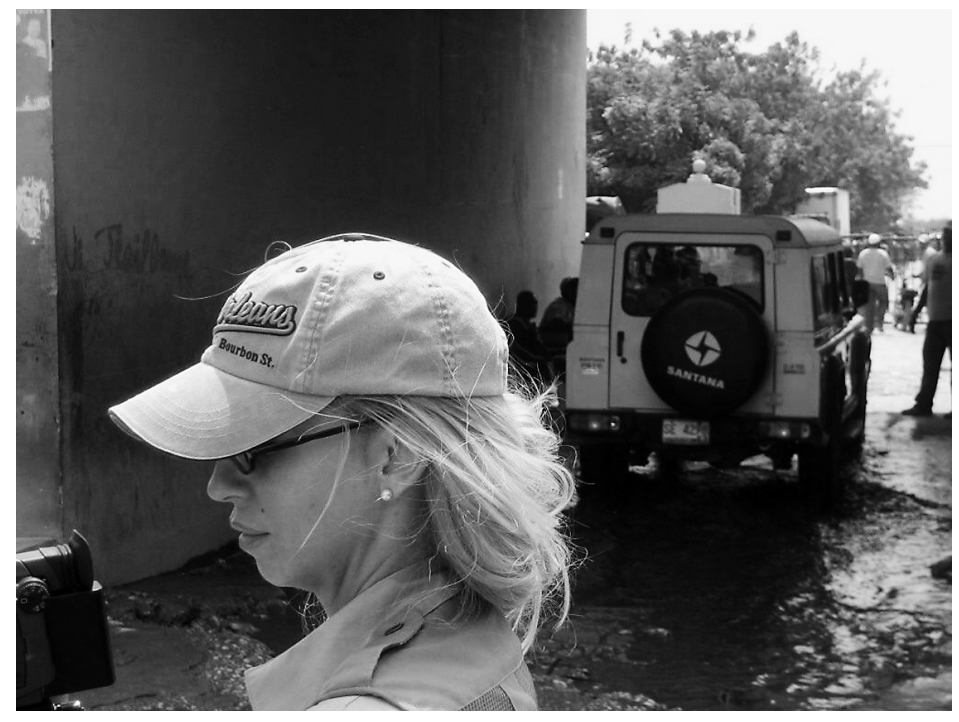

Filmmaker Amy Serrano 


\section{Documenting Modern-Day Slavery in the Dominican Republic: An Interview with Amy Serrano}

Michael T. Martin

Modern-day slavery is the subject of increasing concern and controversy, evidenced by its address in investigative journalism, labor and human rights activism, and, no less, documentary films and videos. While slavery is distinctive in human history, its continuing presence in the modern world is manifest in the "disposable" labor that provisions the brothels and sweatshops in the global economy. It is also among the causes of the seemingly chronic poverty and growing inequalities in an international system of rule and exploitation - what Salih Booker and William Minter refer to as "global apartheid."

This interview with Amy Serrano concerns the documentary The Sugar Babies: The Plight of the Children of Agricultural Workers in the Sugar Industry of the Dominican Republic (US, 2007). ${ }^{2}$ Directed and produced by Serrano, the film is about modern-day slavery and examines the complicity of state governments in human trafficking and the abusive practices against Haitian migrants by sugar barons in the Dominican Republic (DR). The film also illuminates a global

Camera Obscura 74, Volume 25, Number 2

DOI 10.1215/02705346-2010-005 (C) 2010 by Camera Obscura

Published by Duke University Press 
trend in which migrants from poorer countries, unable to emigrate to first-world metropolises, traverse borders - by legal and illegal means-to less poor countries.

When Sugar Babies was shown at Florida International University in June 2007, the Dominican consul stormed out of the screening in protest. ${ }^{3}$ Representatives of the sugar industry in the DR and the US condemned the film, and some journalists were allegedly bribed by the Dominican Consulate General to write negative reviews of the film. ${ }^{4}$ The film's director later withdrew it from the Miami International Film Festival, whose organizers claimed that the film was disqualified because of media coverage of earlier screenings. Sugar Babies continues to stir controversy, and Serrano has been forced to relocate from Florida to Louisiana. In September 2009, according to the Human Rights Foundation, which helped produce the film, the US Department of Labor "included sugarcane from the Dominican Republic on its list of products believed to be made from forced child labor," due in part to the film's influence. ${ }^{5}$

\section{Interview}

Michael T. Martin: Why have you taken up the subject of human trafficking and modern-day slavery in Sugar Babies?

Amy Serrano: Because it is the story of human trafficking and the denial of rights to people who are forced to live without dignity. It is also the story of children who, if things don't change, will have a tragic future. And Sugar Babies is about the sugar we [Americans] consume from plantations in the DR.

What constitutes slavery in its modern-day incarnations?

This is a subject of contention, particularly with people who seek to protect the status quo and plantation system. They claim that people of Haitian ancestry are not brought across the border in ships and shackles; they are allegedly brought of their own free will. But they are lured to the DR, stripped of identity, and rendered immobile by poverty and the denial of citizenship. What 
you typically find on the plantations are men under the hot sun with machetes and women who must feed their children when there are no males present in the household. In other words, the technology has not changed since slavery. This is the only life they know. A man. A machete. And the hot sun.

\section{Fixed in time and immutable?}

Yes, as evidenced in the film by men laboring in the fields. And by their wages, barely enough to feed their families one meal a day. The typical meal is what they call "empty rice," which is rice with nothing — naked rice. "Empty rice" and sugarcane. Also depicted are images of children going into the cane fields for one meal a day. During off-season, or what they call "dead season," many people die of hunger and diseases. They have nothing but sugarcane to eat. Ironically, the same source - sugarcane - that enslaves also feeds them.

Is Sugar Babies a work of agitprop deployed to mobilize against the dehumanizing practices that you chronicled in the film?

Sugar Babies exposes the truth about the conditions we witnessed in the DR. I hope that people will be mobilized to change the conditions in the bateys [sugar plantations] for the children of Haitian migrants. I am not alone in this effort. There are activists on the ground on both sides of the island [Haiti and the DR] who have dedicated their lives to this cause. There are also artist-activists like me in Europe engaged in this issue.

While it is apparent that the children of Haitian migrants are the victims most adversely affected by the practices and abuses of the sugar industry, do they also serve in the film to dramatize first-world audiences' complicity in modern-day slavery?

When I began this project, it was to expose how sugar is a cause of the children's condition. I had no idea at the time about human trafficking or of the DR government's complicity with the sugar industry. I hope that people will see their own child reflected in those in the film. Children are the heart of the film. 
Is race a marker of difference and status in the DR?

The DR gained independence from Haiti, not Spain. So there's this historical enmity in the DR against Haitians. I have never observed and felt such a degree of racism as we did in the DR. On the plantations 95 percent of the workforce that cuts the cane is Haitian, while 5 percent, who are typically referred to as the "boss men," "directors," or "administrators," are Dominicannever Haitian. The Dominicans are very clear about who cuts the cane-the Haitians. The Haitians who were born on the plantations, as well as those who come to the DR, are told by the Dominicans, "We were born to direct you and you were born to follow."

Is race, then, a matter of nationality and language rather than skin color? Without doubt it is. There are horrible things that you encounter in the DR. For example, one of the jokes repeated among Dominicans is that "it is easier to replace a Haitian than a farm animal because you can get five Haitians for the price of one ox." What this means is that, if a Haitian loses a limb or gets sick while working, [he or she is] expendable and replaceable.

\section{Disposable labor.}

If an ox is hurt, the veterinarian is called immediately to take care of it, but not the doctor, if a Haitian is injured.

\section{Does skin color matter in the DR?}

I would say nationality matters more than skin tone. Of course, the whiter you are, the more you are considered part of the power structure. Unfortunately, that's how it is in the world. But it is more prominent on this island, which is inhabited by two countries.

What about the term "Haitian-ness" that is evoked in the film? Is it code for race?

Yes. If you're Haitian, you're black. If you're non-Haitian, you're probably white, even if your skin is darker than a Haitian's. 
What is the relationship between the sugar industry in the DR and the global sugar market?

Wherever sugar exists there is abuse, especially when it is harvested by hand. Fifty-one percent of the sugar in the world is harvested by hand, which means that more than half the world's sugar production will, more often than not, involve abuse. A case in point is Nicaragua, where people die every week in the production of sugar, largely because of pesticides and the lack of proper sanitation and nutrition. The most tragic case, however, is in Brazil, where sugar fields are being converted to produce ethanol. The sugar industry is also linked to the trafficking of the organs of children who work on the sugar plantations there. They are taken to Mozambique and stripped of some of their organs, which are sold to wealthy families who need them for their children in the first world. It all comes back to sugar. Wherever it is harvested, we find exploitation and abuse at the worse levels.

In Sugar Babies you intercut several scenes from Euzhan Palcy's film La Rue Cases Nègres (Sugar Cane Alley, dir. Euzhan Palcy, Martinique/ France, 1982), whose setting is postemancipation Martinique, circa the I930s. What are the similarities between the DR and Martinique?

I conceive of things in terms of points of similarity and departure. For one thing, Martinique and Haiti are plantation societies, and both were colonized by France. I chose Palcy's film because, for Sugar Babies to be understood by audiences, it was necessary to show the transformation of Africans as slaves in the New World to emancipated people who now endure a new form of slavery. We can call it many things, including indentured servitude. While the legal status of the worker may have changed, conditions today are worse than during slavery's past. In [Palcy's characters] Medouze and José, the generations that preceded and follow them find the Sugar Babies. This is dramatized in Medouze's reply to [Amantine's grandson] José: "Damn cane fields. ... All the blacks came down from the hills with sticks, machetes, guns, and torches. They burned all the homes ... that was how slavery ended. . . I saw [postemancipation] I was back in Black Shack Alley again. ... 
It was back to the cane fields. We were free, but our bellies were empty. The Master had become the Boss. So I stayed on, like all the other blacks in this cursed country.... Nothing has changed, son, the whites own all the land."

What purpose was served by using black and white and color alternately in Sugar Babies?

In the opening scenes of the film, children are in color. When we cut to the past they are in black and white. We color treated Palcy's segment, making it black and white to connect to the past. My reason for making this distinction was because we think of the past in black and white and the present in color, although the present hasn't changed much from the past. It was also a way to connect with our perception of time, how we imagine the past from the present, even though in the micro world of the bateys, the past and present neither evolve nor change. For example, the little girl in the first segment of the film whose image was shot two years ago shifts from color to black and white. She could be me in the present and her in the 1800 s. Between the two hundred years, her life would have been unchanged in the bateys of the DR.

How does Sugar Babies differ from Bill Haney's Price of Sugar (US, 2007)?

The Price of Sugar is a biography of Father Hartley, the protagonist and voice for what is happening in the sugar plantations of the DR. The film is set against the backdrop of his parish's struggle against the Vicini family. In contrast, Sugar Babies is focused on children and their families, their arrival to and presence in the DR, and the stories of their mothers. While the films address the same subject, what distinguishes them is how they tell the same story differently. Another difference is that The Price of Sugar was narrated by Paul Newman, ours by Edwidge Danticat.

You claim in the film that Haitian migrants are denied citizenship in the $D R$. How is the denial rationalized by the government? 
The government has several arguments, but the main one is that the parents of the children are in transit and reside illegally in the DR. Therefore why should they grant the children citizenship? My counterargument is, how can you claim that these migrants are in the country illegally when you orchestrated their immigration to the DR?

\section{How is it rationalized by the citizens of the DR?}

They don't want the country to become "Haitianized," arguing that the Haitians are there illegally and taking away jobs from Dominicans, which of course is untrue because no Dominican cuts cane.

Apart from the traumatic experience of repatriation, does the threat of repatriation unnerve Haitians to resist?

It has many functions. The first question someone asks, "Don't they [Haitians] want to return to their country since things are so terrible in the DR?” The truth is that the system of repatriation occurs under terrifying circumstances, that it's better to stay in fear than face the unknown. The deportations are random and usually occur during the night. And what little they have accumulated, they can't take back with them to Haiti. But the worst part is the separation of the families. A colleague, who is a DominicanHaitian woman, handles the cases of families still searching for their children who were separated during the deportations. Two, three years later they still don't know where their children are. The deportations occur this way: trucks come, people are rounded up, the children are separated from their mothers, who are put in a truck and told, "Don't worry, your children will follow in the truck after you, where you'll meet them on the border [with Haiti]." The prospect of finding their children is very problematic because the parents don't know where they are. There are parents who have never recovered their children. 
Is the analogue in modern history the Holocaust?

Father Hartley refers to the border area where Haitians are taken to the sugar plantations as the "threshold to hell." He compares it to Auschwitz or Dachau in the film when the Haitians, waiting on the border dressed in their best attire, are stripped of their clothing before they are transported to the plantations. This practice evokes the comparison of the showers in the concentration camps. And the truth is that the Haitians are not going to the hotel service jobs, et cetera, they were promised before crossing the border.

Is there a similarity between the laboring conditions of Haitian migrants in the DR and agricultural migrants in the US?

You can't compare US migrants to those in the DR because the migrant workers in the US have mobility, whether they have legal status or not. They shop at the same supermarkets we do. They have cars and trucks. They have running water and electricity. And their children can go to school. The children of Haitian migrants in the DR can at best attain a fourth-grade level of education. The migrants have no running water or portable water. When we started going to the camps, the animals and people there largely drank from the same water system, which partially accounts for the diseases and skin conditions of the children in the film. Some of them have diseases they contracted in the bateys that were eradicated in the rest of the world. The HIV rate of infection among the migrants, too, is $13^{-15}$ percent compared to $1-3$ percent in the rest of the population in the DR, and in Haiti, 3-5 percent. So comparisons are not appropriate. To me, the life of Haitian migrant workers is a crime.

Apart from the project of mobilizing support against human trafficking and the batey system in the DR, is Sugar Babies your response to and rejection of NAFTA [North American Free Trade Agreement], CAFTA [Central America Free Trade Agreement], and other pending US bi-and multilateral trade agreements in the Caribbean and Central and South America? 
Some people are for these free trade agreements, others against them. There are those who believe that CAFTA and NAFTA are bad policies, while others believe they are good policies because with them we can spotlight human rights.

Because the agreements have a legal framework with which to contest exploitive practices and human rights abuses?

Exactly.

Do you expect the film to affect people and government policies toward migrants?

I hope that when people see Sugar Babies they become outraged and channel it creatively in whichever way they are called to. When we make change in this small part of the world it creates awareness of the sugar industry in Brazil and Nicaragua and other places where sugar is hand harvested. What we do in one place, as simplistic as it sounds, does affect everyone. It elevates everyone. And that's why I do what I do.

Is the Haitian government complicit in the exportation of Haitians to the $D R$ ?

Another sad aspect of this story is that during the Duvalier era, Haitians were sold to the Dominican side. After their [the Duvaliers'] reign, the practice continued because the infrastructure was there to support it. It is very important that Haiti take responsibility for Haitians. I can tell you that there are NGOs [nongovernmental organizations] that are now working on the island to repatriate Haitians from the DR.

Is there something that I should have asked, but didn't, or something that you want to say but haven't said?

Two points I want to make about poverty in the DR. First, there is much poverty in the DR. I don't want to minimize awareness of this fact because the DR is a developing country. I urge Dominicans to take their government to task because this poverty is 
caused by unemployment. Ironically, Haitians in the bateys are, if anything, overemployed, working twelve to fourteen hours a day for the two wealthiest families [Fanjul and Vicini], yet their lives are more impoverished than poor Dominicans. Poverty among Haitians in the DR is, therefore, of a different order of severity than for Dominicans.

And, second, I want to acknowledge the Dominicans who worked with us to make Sugar Babies. I can't name them because they risk their lives and labor for the freedom of all people. Many Dominicans, on and off the island, understand - in the words of Martin Luther King Jr. - that "injustice against one person is truly an injustice against all.”

Thank you, Amy Serrano.

\section{Notes}

1. Salih Booker and William Minter, "Global Apartheid," Nation, 9 July 2001.

2. The interview was conducted on 7 February 2008, on the occasion of Serrano's visit to Indiana University, where Sugar Babies was screened to student and general public audiences.

3. See Laura Wides-Munoz, "Filmmaker: Sugar Family May Have Blocked Documentary about Them," Miami Herald, 8 March 2008, www.miamiherald.com/775/v-print/story/448810.html.

4. See Siren Studios, "Controversial Human Rights Film to Be Presented at Cinema Paradiso Beginning May 28," press release, 13 May 2008; and en.wikipedia.org/wiki/The _Sugar-Babies (accessed 3 May 2010).

5. See Human Rights Foundation, "HRF's The Sugar Babies at the University of Miami," 6 November 2009, www.humanrights foundation.org/media/1106og.html. Shot on digital beta, the ninety-nine-minute documentary was produced by Siren Studios in association with the Hope, Courage, and Justice Project (New Orleans) and the Human Rights Foundation (New York City). 
Michael T. Martin is the director of the Black Film Center/Archive and a professor of African American and African Diaspora studies at Indiana University, Bloomington. Among his books, he is coeditor of Redress for Historical Injustices in the United States: On Reparations for Slavery, Jim Crow, and Their Legacies (Duke University Press, 2007). His most recent publications also include an essay on Gillo Pontecorvo and Haile Gerima in Third Text 23, no. 6 (2009) and interviews with filmmakers Julie Dash in Cinema Journal 49, no. 2 (2009), Joseph Gai Ramaka in Research in African Literatures 40, no. 3 (2009), Yoruba Richen in the Quarterly Review of Film and Video (forthcoming 2010), and Charles Burnett in Black Camera 1, no. 1 (2009). He also directed and coproduced a documentary on Nicaragua, In the Absence of Peace (1988).

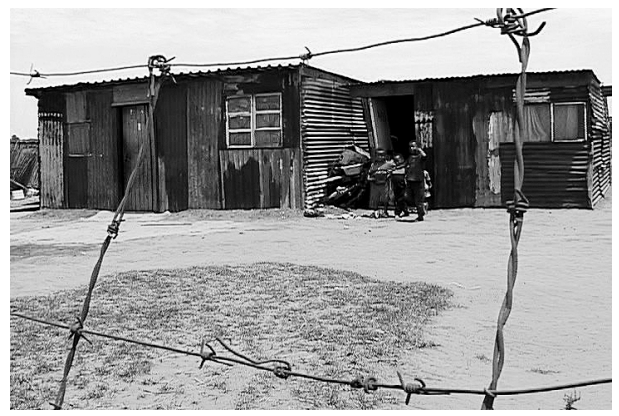

Children in a batey 